\title{
Lung Epithelioid Hemangioendothelioma
}

National Cancer Institute

\section{Source}

National Cancer Institute. Lung Epithelioid Hemangioendothelioma. NCI Thesaurus. Code C4453.

A low-grade malignant blood vessel neoplasm arising from the lung. It is characterized by the presence of epithelioid endothelial cells. The neoplastic cells are arranged in cords and nests, which are embedded in a myxoid to hyalinized stroma. 